\title{
Characterization of Chitosan from the Haliling Snail (Filopaludina javanica) Shell in South Kalimantan
}

\section{Karakterisasi Kitosan dari Limbah Cangkang Siput Haliling (Filopaludina javanica) Kalimantan Selatan}

\author{
Siska Musiam ${ }^{\mathrm{a}, 1, *}$, Noor Aisyah a,2 \\ ${ }^{a}$ Sekolah Tinggi Ilmu Kesehatan ISFI Banjarmasin, Jl. Flamboyan III No. 7C Kayu Tangi, Banjarmasin, Kalimantan Selatan, 70123, Indonesia \\ ${ }^{1}$ siska.musiam@gmail.com*; ${ }^{2}$ aisyah.no2r@gmail.com \\ * corresponding author
}

\section{ARTICLE INFO}

Article history

Received September 17, 2020

Revised January 08, 2021

Accepted January 14, 2021

Keywords

Characterization

Chitosan

Filopaludina javanica

\section{ABSTRACT}

Chitosan is a renewable natural polymer derived from chitin which can be found in many invertebrate animals. Chitosan has non-toxic properties, easily broken down (biodegradable and bioresorbable), and able to adapt to its environment (biocompatibility). This study aims to characterize chitosan produced from haliling (Filopaludina javanica) shell waste originating from South Kalimantan. Haliling meat is consumed as a side dish by the people of South Kalimantan so that the shell becomes a waste that can be used as raw material for chitosan. Chitosan characterization included determination of yield, solubility test, calculation of the degree of deacetylation with Fourier Transform Infra Red (FTIR), as well as observing the crystallinity and morphology of the yield compounds by X-Ray Diffraction (XRD) and Scanning Electron Microscope (SEM). The yield of chitosan obtained was $8.890 \%$ with the best solubility at $0.1 \mathrm{~N} \mathrm{HNO}_{3} \mathrm{~N}$. The FTIR analysis of chitosan obtained a degree of deacetylation of $60.581 \%$. $X R D$ and SEM data showed a crystallinity index of $52.945 \%$ with a granular surface.

This is an open access article under the CC-BY-SA license.

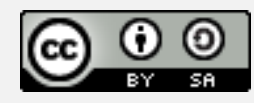

\section{Pendahuluan}

Kitosan adalah senyawa yang diproduksi melalui deasetilasi kitin, yaitu polimer terbanyak kedua di alam setelah selulosa [1]. Kitin banyak ditemukan dalam hewan invertebrata dan dapat diisolasi melalui proses deproteinasi dan demineralisasi [2]. Kitin memiliki rumus kimia $\left(\mathrm{C}_{8} \mathrm{H}_{13} \mathrm{NO}_{5}\right)_{\mathrm{n}}$ yang merupakan polimer anhidro N-asetil-D-glukosamin, sedangkan kitosan didefinisikan sebagai kopolimer dari 1,4-glukosamina $\left(\mathrm{C}_{6} \mathrm{H}_{11} \mathrm{NO}_{4}\right)_{\mathrm{n}}$ dan memiliki jumlah grup $\mathrm{N}$-asetil yang berbeda [3]. Proses deasetilasi kitin untuk membentuk kitosan dilakukan dengan mereaksikan kitin dengan basa kuat yang umumnya digunakan adalah $\mathrm{NaOH}$. Proses ini akan menghasilkan kitosan dengan derajat deasetilasi yang tinggi [4]. Kitosan merupakan polisakarida yang memiliki sifat fungsional seperti aktivitas antioksidan, antimikroba, pembentuk film dan gel, serta potensi enkapsulasi [5]. Hal ini disebabkan pada kitosan memiliki gugus hidroksil $(-\mathrm{OH})$ dan amina $\left(-\mathrm{NH}_{2}\right)$ sehingga reaksinya dapat lebih fleksibel dibandingkan kitin dan selulosa [6]. Kitosan telah diaplikasikan dalam berbagai bidang karena sifatnya yang lebih unggul dibandingkan polimer alam lain, diantaranya sebagai adsorben logam berat, media penyerapan protein dan obat, pengolahan makanan, dan bahan antibakteri [5-13].

Beberapa penelitian sebelumnya telah melaporkan hasil sintesis kitosan dari beberapa cangkang hewan Mollusca seperti kapah, keong mas, dan bekicot [14-16]. Haliling (Filopaludina javanica) 
adalah salah satu hewan Mollusca yang dagingnya dimanfaatkan sebagai lauk makan oleh masyarakat Kalimantan Selatan sehingga cangkangnya menjadi limbah yang berpotensi sebagai bahan baku sintesis kitosan. Senyawa kitosan hasil sintesis perlu dikarakterisasi agar dapat ditentukan sifat-sifatnya sehingga pemanfaatannya dapat disesuaikan dengan karakteristik tersebut. Standar Nasional Indonesia 7949: 2013 menetapkan bahwa standar mutu kitosan yang dapat digunakan untuk aplikasi komersial adalah berwarna coklat muda sampai putih, kelarutan dalam asam $\geq 99 \%$, viskositas $\geq 5 \mathrm{cps}$, derajat deasetilasi $\geq 75 \%$, kadar air $\leq 12 \%$, kadar abu $\leq 5 \%$, dan $\mathrm{pH}$ 7-8 [17].

Kitosan merupakan polimer rantai lurus yang sebagian besar larut dalam asam organik karena memiliki nilai pKa 6,5. Kitosan dengan struktur polimer besar tidak dapat larut dalam air. Kelarutan kitosan akan mempengaruhi kemampuan biodegradasi dan adsorbsinya karena tergantung dari jumlah gugus amino yang terprotonasi dalam rantai polimernya. Faktor lain yang juga mempengaruhi sifat dari kitosan adalah derajat deasetilasi, yaitu perbandingan jumlah unit Dglukosamin yang terasetilasi dan tidak terasetilasi [18]. Semakin tinggi derajat deasetilasi kitosan maka reaktivitasnya juga akan semakin baik [4].

Penelitian ini bertujuan untuk menentukan karakteristik kitosan yang disintesis dari limbah cangkang haliling (Filopaludina javanica) yang berasal dari Kalimantan Selatan. Parameter karakterisasi kitosan yang dilakukan meliputi perhitungan rendemen, uji kelarutan, analisis FTIR, penentuan derajat deasetilasi, kristalinitas (XRD) dan morfologinya (SEM). Parameter ini dipilih untuk menilai tingkatan kualitas dari proses dan hasil sintesis kitosan apakah termasuk dalam kategori rendah, sedang, atau tinggi. Pengujian parameter XRD dan SEM dilakukan untuk melihat karakter mikroskopik dari partikel kitosan yang dihasilkan.

\section{Metodologi Penelitian}

Kitosan yang dikarakterisasi adalah hasil deasetilasi kitin dari limbah cangkang haliling (Filopaludina javanica) yang berasal dari Kalimantan Selatan [19].

\subsection{Peralatan dan Bahan}

Alat-alat yang digunakan adalah neraca analitik, alat gelas, magnetic stirrer, sentrifuge, Fourier Transform Infra Red (FTIR Shimadzu IRPrestige21), X-Ray Diffraction (XRD PanAnalytical X'Pert Pro), Scanning Electron Microscope (SEM VEGA3 TESCAN). Bahan-bahan yang digunakan adalah kitosan dari limbah cangkang haliling, akuades, $\mathrm{CH}_{3} \mathrm{COOH}$ (Merck), $\mathrm{HCl}$ (Merck), $\mathrm{HNO}_{3}$ (Merck), dan kertas saring.

\subsection{Perhitungan Rendemen}

Nilai rendemen (\%rendemen) didapat dengan membandingkan jumlah kitosan hasil sintesis dengan jumlah bahan baku limbah cangkang haliling yang disintesis.

$$
\text { Rendemen }=\frac{\text { massa kitosan hasil sintesis }}{\text { massa limbah cangkang haliling yang digunakan }} \times 100 \%
$$

\subsection{Uji Kelarutan}

Setiap 0,5 gram sampel kitosan dilarutkan ke dalam masing-masing $50 \mathrm{~mL}$ larutan asam asetat $\left(\mathrm{CH}_{3} \mathrm{COOH}\right)$, asam klorida $(\mathrm{HCl})$, dan asam nitrat $\left(\mathrm{HNO}_{3}\right)$, dengan konsentrasi $0,1 \mathrm{~N}$ dan $0,01 \mathrm{~N}$. Kelarutan diamati setiap 30 menit dalam suhu ruang sampai 120 menit [20].

\subsection{Analisis FTIR dan Derajat Deasetilasi}

Spektrum FTIR kitosan dari limbah cangkang haliling diperoleh dengan menggunakan spektrofotometer FTIR (Shimadzu IRPrestige21) pada kisaran bilangan gelombang 4000-400 $\mathrm{cm}^{-1}$ dengan akumulasi rekaman 40 scan dan resolusi $4 \mathrm{~cm}^{-1}$. Derajat deasetilasi (\%DD) dihitung dengan menggunakan data gugus fungsi yang muncul pada spektrum FTIR sesuai dengan metode garis oleh Moore dan Robert [21].

$$
\text { Derajat Deasetilasi }=\left(1-\left(\frac{A_{1655}}{A_{3450}} \times \frac{1}{1,33}\right)\right) \times 100 \%
$$




\subsection{Perhitungan Rendemen}

Karakterisasi struktur dan kristalinitas kitosan ditentukan dengan menggunakan XRD (PanAnalytical X'Pert Pro). Kristalinitas sampel kitosan diamati dari pola difraksinya dengan menggunakan radiasi $\mathrm{Cu}-\mathrm{K} \alpha(\lambda=0,15406 \mathrm{~nm})$ pada $40 \mathrm{kV}$. Intensitas relatif dicatat pada kisaran hamburan $2 \theta$ antara $10-90^{\circ}$. Indeks kristalinitas dapat dihitung dengan persamaan berikut [9]:

$$
\text { Indeks kristalinitas }(\%)=\frac{F c}{F c+F a} \times 100 \%
$$

Morfologi dari sampel kitosan diamati melalui metode visualisasi dengan SEM (VEGA3 TESCAN) dengan tegangan $20 \mathrm{kV}$ dan perbesaran mulai 1500-10000 kali.

\section{Hasil dan Pembahasan}

\subsection{Perhitungan Rendemen}

Perhitungan rendemen bertujuan untuk menilai efektivitas proses yang telah dilakukan dari seberapa banyak produk kitosan yang didapat. Serbuk cangkang haliling yang digunakan pada proses isolasi kitin adalah sebanyak 50,060 gram. Isolasi kitin dilakukan melalui proses deproteinasi, demineralisasi, dan depigmentasi sehingga didapatkan kitin sebanyak 8,514 gram. Sebanyak 7,919 gram hasil isolasi kitin dilakukan proses deasetilasi dan didapatkan kitosan sebanyak 4,448 gram sehingga rendemen yang didapatkan adalah $8,890 \%$.

Nilai rendemen kitosan ini lebih kecil dibandingkan dengan kitosan yang disintesis dari cangkang udang $( \pm 20 \%)$ dan cangkang kepiting (10\%) [22]. Hal ini menunjukkan bahwa jumlah kitosan yang didapatkan bergantung pada sumber kitinnya. Sifat fisika dan kimia kitin tidak stabil karena dipengaruhi oleh fisiologi dari organismenya. Semakin besar kandungan protein di dalam sumber kitin maka semakin banyak jumlah kitin yang dapat diisolasi [23]. Udang dan kepiting merupakan hewan laut yang kandungan proteinnya dapat lebih tinggi dibandingkan haliling yang merupakan hewan air tawar, karena suhu air laut yang dalam bisa mempengaruhi temperatur fisiologis hewan laut untuk membentuk asam lemak esensial [24]. Protein dan kitin berikatan secara kovalen membentuk suatu senyawa kompleks yang stabil. Banyaknya kitin yang bisa diisolasi dari suatu organisme bergantung pada proses deproteinasinya. Keberadaan protein akan mempengaruhi kelarutan dari kitin dan kitosan [4].

\subsection{Uji Kelarutan}

Uji kelarutan berfungsi untuk melihat ketahanan kitosan yang dihasilkan dalam larutan asam. SNI 7949: 2013 menyebutkan bahwa kitosan yang dapat digunakan untuk aplikasi komersial harus memiliki kelarutan dalam asam minimal 99\%. Oleh karena itu, pada tahap ini dilakukan uji kelarutan dengan menggunakan beberapa jenis asam dan konsentrasi yang berbeda. Larutan asam yang digunakan adalah asam asetat $\left(\mathrm{CH}_{3} \mathrm{COOH}\right)$, asam klorida $(\mathrm{HCl})$, dan asam nitrat $\left(\mathrm{HNO}_{3}\right)$, masing-masing dengan konsentrasi $0,1 \mathrm{~N}$ dan $0,01 \mathrm{~N}$. Pengamatan kelarutan dilakukan pada menit ke-30, 60, 90, dan 120 disajikan pada Tabel 1.

Tabel 1. Hasil uji kelarutan kitosan

\begin{tabular}{ccccccc}
\hline Waktu & \multicolumn{2}{c}{$\mathbf{C H}_{\mathbf{3}} \mathbf{C O O H}$} & \multicolumn{2}{c}{$\mathbf{H C l}$} & \multicolumn{2}{c}{$\mathbf{H N O}_{\mathbf{3}}$} \\
\cline { 2 - 6 } (menit) & $\mathbf{0 , 1} \boldsymbol{N}$ & $\mathbf{0 , 0 1} \boldsymbol{N}$ & $\mathbf{0 , 1} \boldsymbol{N}$ & $\mathbf{0 , 0 1} \boldsymbol{N}$ & $\mathbf{0 , 1} \boldsymbol{N}$ & $\mathbf{0 , 0 1} \boldsymbol{N}$ \\
\hline 30 & tidak larut & tidak larut & tidak larut & tidak larut & larut & tidak larut \\
60 & tidak larut & tidak larut & tidak larut & tidak larut & larut & tidak larut \\
90 & larut & tidak larut & tidak larut & tidak larut & larut & tidak larut \\
120 & larut & tidak larut & larut & tidak larut & larut & tidak larut \\
\hline
\end{tabular}

Keberadaan asam akan mempengaruhi kelarutan kitosan karena asam yang dilarutkan akan melepaskan ion hidrogen yang mampu memutus ikatan hidrogen pada gugus amina rantai polimer kitosan yang kerapatannya sangat tinggi. Ikatan hidrogen tersebut sangat kuat menyebabkan kitosan tidak mudah larut dalam $\mathrm{pH}$ netral seperti air, sehingga penambahan asam akan mempercepat kelarutan [20]. Pada penelitian ini larutan asam dengan konsentrasi 0,01 $\mathrm{N}$ tidak ada yang mampu melarutkan kitosan karena jumlah ion hidrogen yang dilepaskan oleh asam encer tersebut masih terlalu kecil untuk memutus ikatan polimer kitosan. Pada konsentrasi 0,1 N, asam nitrat lebih mudah 
melarutkan kitosan dibandingkan asam klorida maupun asam asetat. Hal ini kemungkinan disebabkan $\mathrm{HCl}$ merupakan asam kuat yang langsung terdisosiasi dalam air sehingga tidak dapat memutuskan ikatan polimer kitosan, sedangkan $\mathrm{CH}_{3} \mathrm{COOH}$ merupakan asam lemah yang memiliki gugus karboksil yang setelah beberapa saat dapat berikatan hidrogen dengan gugus amina dari polimer kitosan sehingga terjadi pelarutan.

\subsection{Analisis FTIR dan Derajat Deasetilasi}

Spektroskopi infra merah digunakan untuk menentukan gugus fungsi yang muncul dan mengonfirmasi bahwa kitosan berhasil disintesis, digambarkan pada Gambar 1. Kemunculan puncak spektrum yang teramati pada bilangan gelombang $3600-3200 \mathrm{~cm}^{-1}$ merupakan regangan dan vibrasi dari kelompok gugus fungsi hidroksi (-OH) alifatik. Pada bilangan gelombang $3500-3300 \mathrm{~cm}^{-1}$ muncul puncak yang menunjukkan adanya vibrasi - $\mathrm{NH}$ amida. Puncak pada bilangan gelombang 2970-2850 $\mathrm{cm}^{-1}$ dan 1470-1340 $\mathrm{cm}^{-1}$ menunjukkan adanya gugus - $\mathrm{CH}$ alkana. Berdasarkan kemunculan spektrum tersebut dapat disimpulkan bahwa kitosan berhasil disintesis dari cangkang limbah haliling.

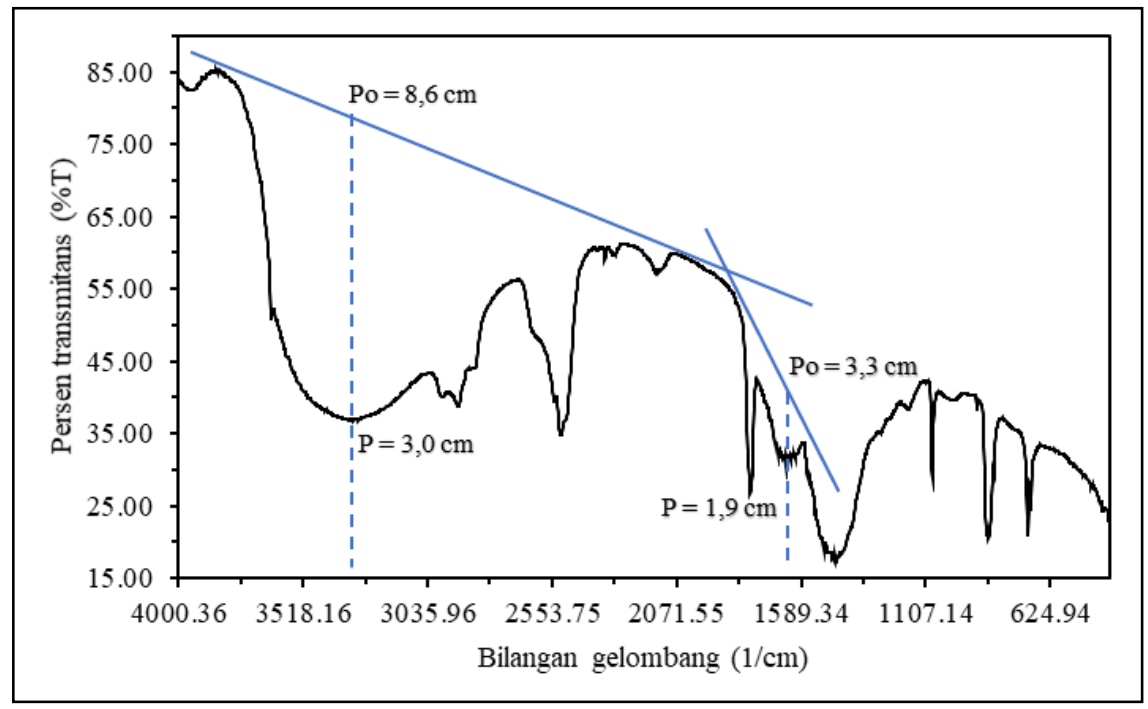

Gambar 1. Spektrum FTIR kitosan cangkang haliling

Derajat deasetilasi (\%DD) kitosan penting untuk ditentukan karena mempengaruhi sifat fisik, kimia, dan biologi dari kitosan. \%DD kitosan berkisar antara 56-99\% [4]. \%DD kitosan yang akan digunakan untuk aplikasi komersial minimal 75\% [17]. Pada penelitian ini didapatkan derajat deasetilasi sebesar 60,581\%, sehingga kitosan tersebut belum memenuhi persyaratan SNI 7949: 2013 untuk dapat digunakan dalam aplikasi komersial. Nilai ini menunjukkan bahwa gugus asetil masih banyak berikatan di dalam rantai polimernya. Ikatan pada gugus $\mathrm{N}$-asetil kitin sulit untuk dihilangkan karena metode preparasinya memerlukan basa konsentrasi tinggi $(\mathrm{NaOH})$ pada temperatur tinggi. Proses demineralisasi, deproteinasi, dan deasetilasi yang dilakukan terhadap kitin belum secara optimal menghilangkan gugus asetil. Hal ini bisa dipengaruhi oleh ketidakstabilan suhu, waktu reaksi yang kurang lama, dan juga proses pengadukan [20].

\subsection{Kristalinitas (XRD) dan Morfologi (SEM)}

Sampel kitosan hasil sintesis menunjukkan pola refleksi yang kuat pada $2 \theta$ sekitar $23^{\circ}$ dan $2 \theta$ sekitar $29^{\circ}$, tersaji pada Gambar 2. Luas area puncak kristalin dan amorf ditentukan dengan metode full width at half maximum (FWHM). Untuk puncak amorf (Fa) pada $23^{\circ}$ didapatkan luas puncak 0,1574 dan untuk puncak kristalin $(\mathrm{Fc})$ pada $29^{\circ}$ didapatkan luas puncak 0,1771 sehingga didapatkan indeks kristalinitas sebesar 52,945\%.

Nilai indeks kristalinitas menunjukkan bahwa kitosan hasil sintesis memiliki struktur campuran antara kristal dan amorf. Kitosan berstruktur amorf lebih bermanfaat dalam dunia kesehatan, karena mudah diabsorbsi dan bioavailabilitasnya lebih baik. 


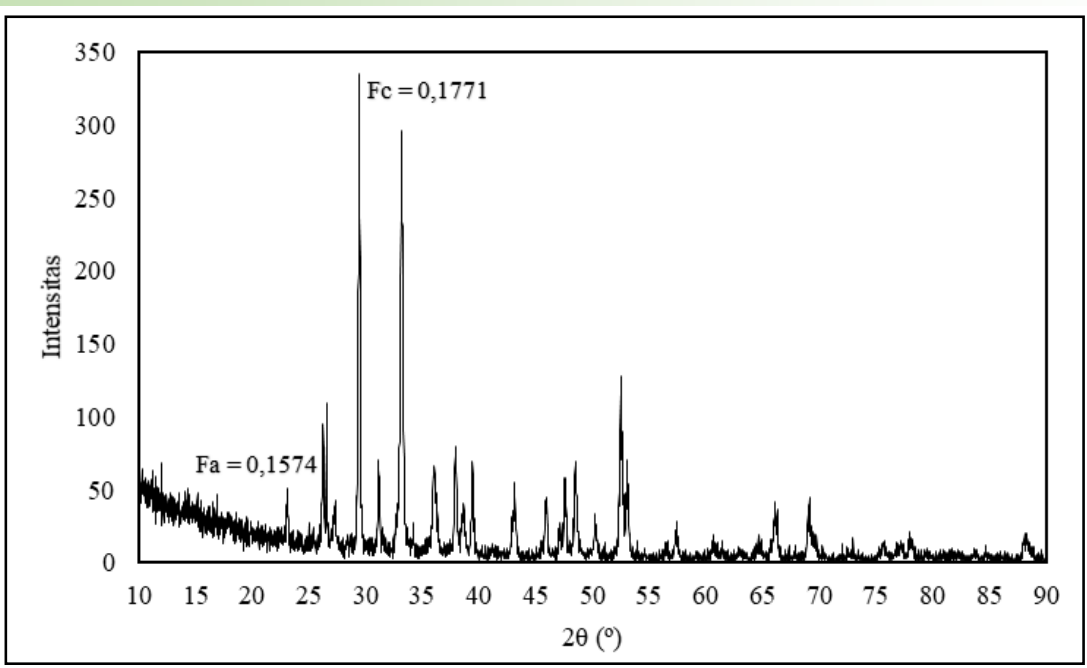

Gambar 2. Pola difraksi kitosan cangkang haliling

Morfologi sampel kitosan diamati menggunakan SEM dengan berbagai perbesaran dan area yang berbeda-beda, tersaji pada Gambar 3. Gambar SEM menunjukkan kitosan hasil sintesis memiliki permukaan granul dengan bentuk dan ukuran partikel yang beragam. Hasil ini sesuai dengan penelitian sebelumnya yang menyatakan bahwa kitosan berbentuk serat dan granul dengan permukaan yang halus [25].

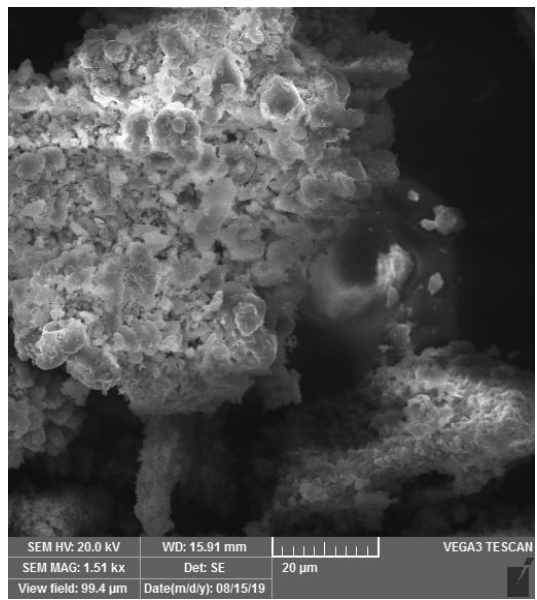

(a)

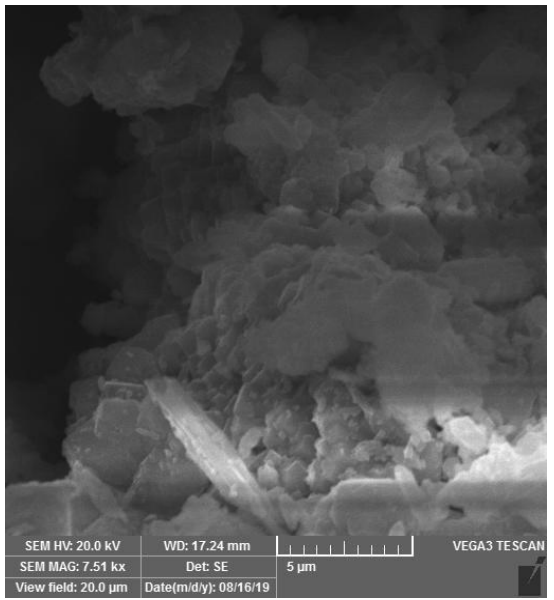

(c)

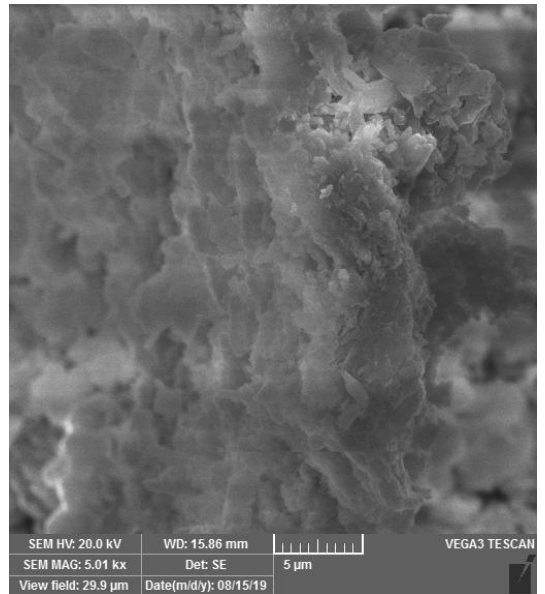

(b)

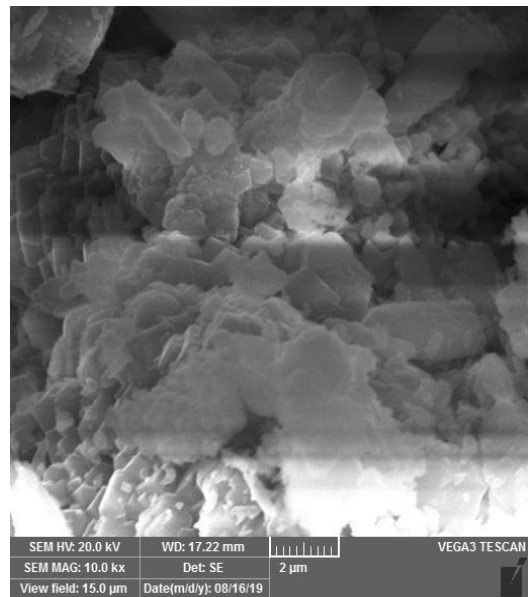

(d)

Gambar 3. Hasil SEM kitosan cangkang haliling: (a) perbesaran 1500x; (b) perbesaran 5000x; (c) perbesaran $7500 x$; (d) perbesaran $10000 x$ 
Berdasarkan hasil karakteristik yang telah ditentukan maka dapat diketahui bahwa kitosan yang dihasilkan belum dapat digunakan untuk aplikasi komersial terutama dalam bidang pangan, farmasi, dan kosmetika. Pemanfaatan yang memungkinkan untuk kitosan ini adalah sebagai adsorben misalnya pada limbah logam berat atau zat warna, juga sebagai bahan baku pembuatan membran misalnya untuk ultrafiltrasi pengolahan air. Hal ini dikarenakan partikel kitosan yang berbentuk granul dan indeks kristalinitasnya yang masih di atas amorf sehingga lebih berpotensi untuk dimanfaatkan secara anorganik. Selain itu, masih dapat dilakukan penelitian lanjutan untuk meningkatkan kualitas kitosan yang dihasilkan dengan memodifikasi proses sintesisnya sehingga dapat digunakan secara komersial.

\section{Kesimpulan}

Karakterisasi kitosan yang disintesis dari limbah cangkang haliling (Filopaludina javanica) Kalimantan Selatan telah dilakukan. Rendemen hasil kitosan yang diperoleh sebesar 8,890\% dengan kelarutan yang paling baik pada $\mathrm{HNO}_{3} 0,1 \mathrm{~N}$. Analisis FTIR kitosan didapatkan derajat deasetilasi sebesar 60,581\%. Data XRD dan SEM menunjukkan indeks kristalinitas sebesar 52,945\% dengan permukaan yang berbentuk granul.

\section{Notasi}

$A_{1655}=$ pita serapan gugus amida

$A_{3450}=$ pita serapan gugus hidroksil

$A \quad=\log (\mathrm{Po} / \mathrm{P})$

Po $\quad=$ persen transmittan pada garis datar

$P \quad=$ persen transmittan pada puncak minimum

$F c \quad=$ luas area puncak kristalin pada $2 \theta=20^{\circ}$

$\mathrm{Fa} \quad=$ luas area puncak amorf pada $2 \theta=10^{\circ}$

\section{Ucapan Terima Kasih}

Peneliti mengucapkan terima kasih atas didanainya penelitian ini oleh Kementerian Riset, Teknologi, dan Pendidikan Tinggi melalui skema Penelitian Dosen Pemula sesuai dengan perjanjian/kontrak nomor 630/L11/KM/2019.

\section{Daftar Pustaka}

[1] B. Hastuti and N. Tulus, "Sintesis Kitosan dari Cangkang Kerang Bulu (Anadara inflata) sebagai Adsorben Ion Cu2+," in Seminar Nasional Kimia dan Pendidikan Kimia VII, 2015.

[2] C. A. Akmarina and Sriwidodo, "Artikel Review: Aplikasi Kitosan dalam Bidang Farmasetik," Farmaka, vol. 14, no. 2, pp. 318-330, 2016.

[3] D. Zvezdova, "Synthesis and characterization of chitosan from marine sources in Black Sea," in Annual Proceedings, 2010, pp. 65-69.

[4] D. Sugiyanti, P. Darmadji, S. Anggrahini, C. Anwar, and U. Santoso, "Preparation and Characterization of Chitosan from Indonesian Tambak Lorok Shrimp Shell Waste and Crab Shell Waste," Pakistan J. Nutr., vol. 17, no. 9, pp. 446-453, 2018.

[5] B. Liu, D. Wang, G. Yu, and X. Meng, "Adsorption of heavy metal ions, dyes and proteins by chitosan composites and derivatives,” J. Ocean Univ. China, vol. 12, no. 3, pp. 500-508, 2013.

[6] S. Pokhrel, P. N. Yadav, and R. Adhikari, "Applications of Chitin and Chitosan in Industry and Medical Science : A Review,” Nepal J. Sci. Technol., vol. 16, no. 1, pp. 99-104, 2015.

[7] A. Fadli, Ervina, Drastinawati, and F. Huda, "Sintesis Kitosan Dari Cangkang Udang," 2016, no. October, pp. 16-23.

[8] A. Khdair et al., "Modified-chitosan nanoparticles: Novel drug delivery systems improve oral bioavailability of doxorubicin," Eur. J. Pharm. Sci., vol. 93, pp. 38-44, 2016.

[9] H. El Knidri, R. El Khalfaouy, A. Laajeb, A. Addaou, and A. Lahsini, "Eco-friendly extraction and characterization of chitin and chitosan from the shrimp shell waste via microwave irradiation," Process Saf. Environ. Prot., vol. 104, pp. 395-405, 2016. 
[10] S. Yudhasasmita and A. P. Nugroho, "Sintesis dan Aplikasi Nanopartikel Kitosan Sebagai Adsorben Cd dan Antibakteri Koliform,” Biog. J. Ilm. Biol., vol. 5, no. 1, pp. 42-48, 2017.

[11]H. E. Irianto and I. Muljanah, "Proses dan Aplikasi Nanopartikel Kitosan sebagai Penghantar Obat," Squalen, vol. 6, no. 1, pp. 1-8, 2011.

[12]E. Rismana, S. Kusumaningrum, O. Bunga, Nizar, and Marhamah, "Pengujian Aktivitas Antiacne Nanopartikel Kitosan - Ekstrak Kulit Buah Manggis (Garcinia mangostana)," Media Litbangkes, vol. 24, no. 1, pp. 19-27, 2014.

[13] C. Huang, K. G. Neoh, L. Xu, E. T. Kang, and E. Chiong, "Polymeric Nanoparticles with Encapsulated Superparamagnetic Iron Oxide and Conjugated Cisplatin for Potential Bladder Cancer Therapy," Biomacromolecules, vol. 13, no. 8, pp. 2513-2520, 2012.

[14]E. Prayogo and D. Rachmawani, "Studi Kandungan Kitosan Cangkang Kapah (Meretrix sp.) di Pantai Amal Lama," vol. 4, no. 2, pp. 21-28, 2011.

[15]P. M. Budi and S. H. Mafidyah, "Pembuatan Kitosan dari Cangkang Keong Mas untuk Adsorben Fe pada Air Sumur," Universitas Sebelas Maret, 2014.

[16] S. Victor M., B. Andhika, and I. Syauqiah, "Pemanfaatan Kitosan dari Limbah Cangkang Bekicot (Achatina fulica) sebagai Adsorben Logam Berat Seng (Zn)," Konversi, vol. 5, no. 1, pp. 22-26, 2016.

[17]W. Syahputra, Satriananda, and Munawar, "Sintesa dan Karakterisasi Hibrid Kitosan-Limbah Kulit Pisang dengan Berpenguat Lignin Sebagai Pembalut Luka Antibakterial," in Proceeding Seminar Nasional Politeknik Negeri Lhokseumawe, 2018.

[18]K. Irnanda, "Pemanfaatan Kitosan Teradiasi Sinar Gamma 25 kGray dalam Formulasi Nanopartikel Gamavuton-0 dengan Penaut Silang Natrium Tripolifosfat secara Gelasi Ionik," Universitas Gadjah Mada, 2014.

[19] S. Musiam and N. Aisyah, "Sintesis Nanokitosan dari Limbah Cangkang Haliling (Filopaludina javanica) Kalimantan Selatan," J. Ilm. Ibnu Sina, vol. 4, no. 2, pp. 430-437, 2019.

[20] Komariah, "Karakterisasi Kitin dan Kitosan yang Terkandung dalam Eksoskeleton Kutu Beras (Sitophilus oryzae)," in Seminar Nasional X Pendidikan Biologi FKIP UNS, 2013, pp. 1-9.

[21]Z. N. Rochmawati, F. Nabila, and C. Ainurrohmah, "Karakterisasi Kitosan yang Diisolasi dari Cangkang Internal Cumi-cumi," Sainteknol, vol. 16, no. 1, pp. 105-111, 2018.

[22] S. Hajji et al., "Structural differences between chitin and chitosan extracted from three different marine sources," Int. J. Biol. Macromol., vol. 65, pp. 298-306, 2014.

[23] M. S. Benhabiles, R. Salah, H. Lounici, N. Drouiche, M. F. A. Goosen, and N. Mameri, "Antibacterial activity of chitin, chitosan and its oligomers prepared from shrimp shell waste," Food Hydrocoll., vol. 29, pp. 48-56, 2012.

[24]R. N. Sukmasari, "Ikan Air Laut Vs Ikan Air Tawar, Mana yang Gizinya Lebih Baik?," detikHealth, 2016.

[25] S. Kumari, S. H. K. Annamareddy, S. Abanti, and P. K. Rath, "Physicochemical properties and characterization of chitosan synthesized from fish scales, crab and shrimp shells," Int. J. Biol. Macromol., vol. 104, pp. 1697-1705, 2017. 